\title{
Potential for increasing the efficiency of design processes for mining the solid mineral deposits based on digitalization and advanced analytics
}

\author{
Yerzhan Uteshov $^{1 \otimes(\bullet}$, Daniyar Galiyev ${ }^{1 * \otimes \bullet}$, Seitgali Galiyev ${ }^{2 \otimes(\bullet)}$ \\ Kanay Rysbekov $^{1 \bowtie(\mathbb{D})}$, Dilda Nauryzbayeva ${ }^{1 凶(\mathbb{D})}$ \\ ${ }^{1}$ Satbayev University, Almaty, 50013, Kazakhstan \\ ${ }^{2}$ Institute of Mining named after D.A. Kunaev, Almaty, 50046, Kazakhstan \\ *Corresponding author: e-mail d.galiyev@ satbayev.university, tel. +77773012986
}

\begin{abstract}
Purpose. The research purpose is to develop and adapt the existing scientific-methodological, as well as software and information base for managing the geotechnological complexes to implement the process approach at the level of design and operation of mining-and-transport complexes during opencast mining. The development is associated with the coverage of more and more relevant options for excavating-conveying, as well as excavating-automobile-conveying mining-andtransport systems used in quarries.
\end{abstract}

Methods. The methodology for managing the geotechnological complexes involves an adequate step-by-step accounting and appropriate operational regulation of all the main factors in specific mining-engineering, mining-geometrical, miningand-geological, economic and organizational conditions. The method of simulation logical-statistical modelling of miningand-transport processes is used as the main method.

Findings. The results indicate that simplified analytical approaches and inadequately considered factors that have a significant impact on the efficiency of mining operations lead to significant errors (10-20\% or more) that determine the real practical profitability of the mineral deposits development.

Originality. Scientific novelty is an integrated approach to a single research object, which is a geotechnological complex, a unique simulation logical-statistical modelling of mining-and-transport processes, the economics of process management, as well as integrated and corporate process management.

Practical implications. The obtained results of an integrated technical and technological audit of a project for mining the coal deposit, with sufficient accuracy for practical application, will ensure the methodological base development for the designing, planning and management of mining and mining-transport operations, as well as an increase in the efficiency of scientific and scientific-practical research in this direction when solving the practical tasks of mining sector.

Keywords: mineral deposits, simulation modelling, geotechnological complex, process, management

\section{Introduction}

The process of digitalization, automation and development of information technologies is extremely relevant in the framework of the world's economies transition to the stage of industrialization "Industry 4.0", where all these directions are the main drivers [1], [2]. The methodological support, which allows, on a broader information basis, to carry out a qualitative analysis of the effectiveness of the complex technological processes functioning is insufficiently developed. At the present stage of industrial development, this is one of the main and systemic problems leading to the low efficiency of digitalization processes and the information technologies development.
With respect to the processes of design and planning mining operations, the enlarged calculations without adequate consideration of detailing make an influence on the quality of design decisions [3], [4]. This causes significant technical and technological, as well as technical and economic system-level inconsistencies, which cannot be negated at the organizational level at the stage of operating the designed mining-andtransport and geotechnological complexes [5]-[7]. Otherwise, they require significant additional capital investments that significantly reduce the profitability level during the mineral deposits development.

When the industrialization stage reaches the "Industry 4.0" level, it is fundamentally important to use a unified 
methodological base both at the design and planning stages, and at the stages of operating the geotechnological complexes. High-quality digitalization and the corresponding advanced analytics are a prerequisite for an effective, timely and sustainable process of technological modernization, which, in turn, ensures the proper competitiveness of mining enterprises and the profitability in the development of the country's mineral resource base [8]. In the conditions of Kazakhstan's economy, this relevance is enhanced by the fact that the mining industry is a basic and decisive in the course of industrialinnovative development of the country [9]-[10].

At the new stage of industrialization, when an adequate consideration of the multifactorial and dynamic natural manifestations is becoming increasingly relevant, a paradigm shift in the development of the methodology for understanding the world is an important peculiarity [11]. Under these conditions, the mathematical description, presentation of direct and curvilinear dependences and patterns is insufficient. Adequate detailing and reproduction of the studied events is required corresponding to logic and sequence, which is associated with the specific analytics development of the studied processes. In this regard, the writing team for about 40 years has been developing a methodology for step-by-step research, analysis and optimization of technological processes in the field of opencast mining of mineral deposits.

This direction is the basis of the process management of the geotechnological complexes operation, as well as the corresponding economics of process management, which is fundamentally and qualitatively new and requires appropriate scientific support. This direction covers all the main functions of management - accounting, control, organization, planning, normalizing, stimulating and regulation. A unified methodology in interrelation and interaction should take into account the nature, principles and content of the listed management functions, which is a fundamental scientific and practical novelty of the approach.

The research purpose is to assess the effectiveness of digitalization tools and advanced analytics methodology, based on the design process of mining-and-transport operations, developed as part of research work performed under the program of state program-targeted financing of fundamental and applied research for 2018-2020 and improved for the existing specifics [12]-[15].

At the first stage, the research objective is to analyse the directions for improving the methodology of advanced analytics based on the step-by-step digitalization of production processes.

The second objective is to determine the real potential for increasing its efficiency from their practical application [16]-[20]. For this purpose, a comprehensive technical and technological audit of a number of specific projects for mineral deposits development has been fulfilled on the example of one of which the main conclusions and findings are substantiated.

The third objective of the conducted research involves the experimental-industrial testing of a unified methodological base for conducting comprehensive technical and technological audits of functioning the mining enterprises geotechnological complexes, assessing its application both at the design and planning stage, and at the stage of mining fields exploitation.

\section{Methods}

\subsection{Research approach methodology}

During the research, within the framework of a systematic approach to the studied object and on the basis of a process approach to the management of geotechnological complexes, as complex and scaled systems, the method of simulation logical-statistical modelling of mining-and-transport processes is used as the main method, which ensures an adequate step-by-step accounting of mining-engineering, mining-geometrical, mining-and-geological, economic and organizational conditions of their functioning. The research is performed by the method of options using a comparative technical and economic analysis. Within the framework of the adopted approach, the tasks are consistently solved of adequate in terms of reliability simulation modelling of the geotechnological complexes functioning of quarries, assessing their qualitative correspondence to real objects of research, conducting a multivariate and multi-criteria analysis of the effectiveness of the geotechnological complexes functioning, identifying the potential for increasing efficiency and the directions of its implementation.

The project for the coal industrial development in the open-cut colliery No. 3 of the Kushmurun field provides for the total period of the field development -45 years, of which 5 years is the preparatory period. By 2025, it is planned to reach the production capacity of the field with the production of 6.4 million tons of coal and 30 million $\mathrm{m}^{3}$ of overburden rock.

The surface plan of the open-cut colliery and dumps location is shown in Figure 1. The project provides for the use of combined technological equipment in overburden and mining operations: for mining - Hitachi EX1900-6 excavators (10 $\mathrm{m}^{3}$ bucket volume) and Hitachi EH1700 coal hauler trucks with a body volume of $100 \mathrm{~m}^{3}$; for overburden operations - Hitachi EX5600-6 excavators with a bucket volume of $35 \mathrm{~m}^{3}$ and Hitachi EH3500 dump trucks with a lifting capacity of 185 tons. The number of simultaneously mined horizons in the quarry is taken according to the project 4 overburden and 2 - production.

The project determines the average technical speed of dump trucks in compliance with the Rules of ensuring industrial safety for the hazardous production facilities conducting mining and exploration works. Taking into account the traffic rules and dump trucks technical capabilities, the motion speeds on certain route sections are taken in the following values: along the horizons $-15 \mathrm{~km} / \mathrm{h}$ with cargo and empty direction; on access tracks -16 and $30 \mathrm{~km} / \mathrm{h}$, respectively; along the surface $-30 \mathrm{~km} / \mathrm{h}$; on dumps and in warehouses $-15 \mathrm{~km} / \mathrm{h}$.

The distance of the useful component transportation from the face areas to the coal transfer warehouse at the time of reaching the production capacity, according to the project, is $4.2-4.83 \mathrm{~km}$. The distance of the overburden rock mass transportation is $7 \mathrm{~km}$.

The highway models taken for research fully correspond to the design geometry of the open-cut colliery and the location of loading and unloading points (faces, warehouses, dumps, shift change point), as follows from Figure 2.

The highway parameters correspond to the dump truck dimensions adopted by the project for operation, as well as to the specific mining-engineering and mining-geometrical parameters of the modelled geotechnological complexes. 


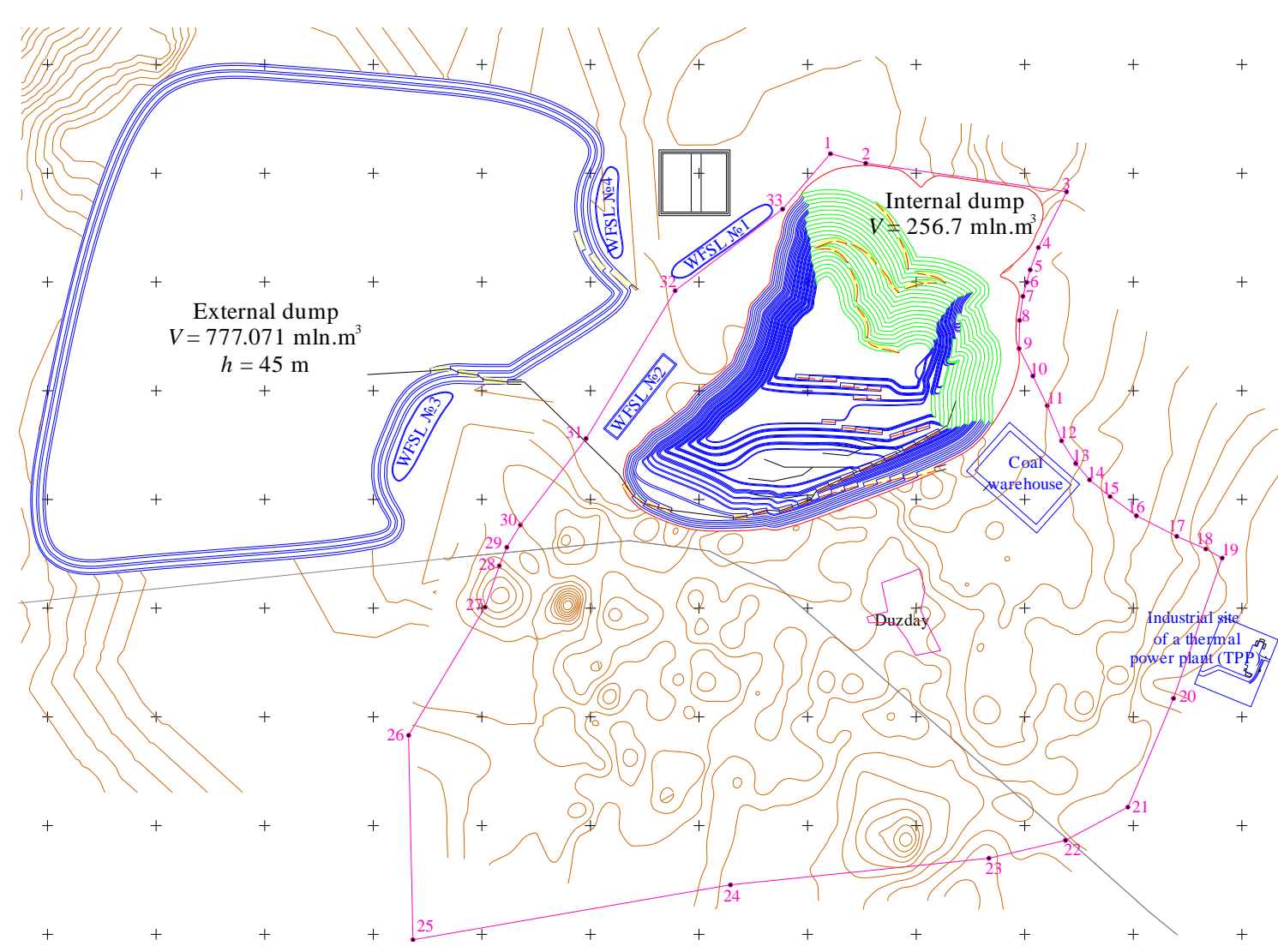

Figure 1. Surface plan of the Kushmurun open-cut colliery: WFSL-warehouse of the fertile soil layer

The spatial geometry of the quarry space is fairly reflected by the highways geometry shown in Figure 2. This is a matter of principle for adequate consideration of speed modes and traffic management when calculating energy consumption both for dump trucks and for road sections.

(a)

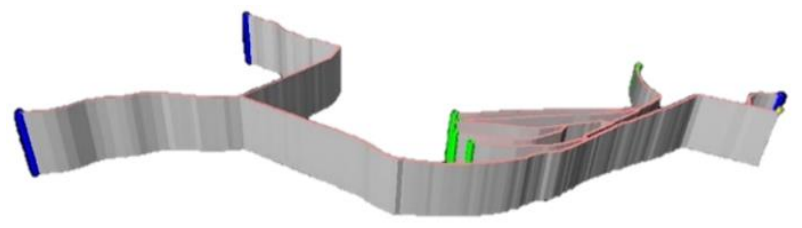

(b)

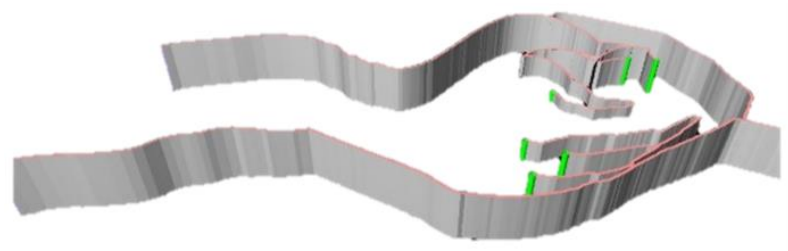

Figure 2. Schemes of highway models of the mining-andtransport system at: (a) single-flank mining; (b) doubleflank mining of the Kushmurun field

The project provides for the type of surfacing as rolled earth surface. The speed limits in the dynamic simulation model are adopted according to the project for each type of route section. The dynamic simulation model includes a 2 -shift and 12-hour work shift of 4 teams, as is the case on real objects. The basic option is the simulation model option that is the most appropriate for the project at the moment of field development.

In the process of research, the options of single-flank and double-flank field development are consistently studied. Different options are modelled in turn, taking into account the principal factors step by step. The description of each of the studied options makes possible to reveal the specifics of the new research methodology and the search algorithm for ways to increase the efficiency and reduce the cost of mining-and-transport operations.

\section{Results and discussion}

As noted in the previous section, it is fundamentally important in the research process to adequately consider the general organizational and economic conditions of the studied geotechnological complexes exploitation, which are set in the design process. For example, the expected period of field exploitation and adopted performance can significantly predetermine the economic effect of certain management decisions developed on the basis of the new methodology.

Option 1 - fully reproduces the situation according to the design data. By option 1 modelling, it is evident that one of the main applied approach disadvantages is the lack of accounting for the costs on tires, as well as the influence of the technical state of vehicles on their efficiency and the performance of mining-and-transport complex as a whole. It is known that tires account for a significant share of the total costs of mining-and-transport operations. The specific volume of costs for tires in the overall balance of operation costs ranges from 10 to $25 \%$, depending on the motor vehicle category. The lack of such accounting leads to underestimation of the real cost of mining-and-transport operations 
during the design and, thereby, to an incorrect determination of the profitability of the field development.

Option 2 is a method of calculations according to the mining-and-transport complex project of the Kushmurun open-cut colliery, implemented as part of an automated design approach based on the application of the simulation modelling method [21]-[23]. The data obtained in the first calculation option are taken as the initial data for it.

The difference of the options in terms of the shift time duration of the mining-and-transport complex operation is conditioned by the differences in approaches and capabilities when performing design calculations. The shift time for the project, equal to 660 minutes, is determined by the existing standards with account of such factors as climatic conditions per year, technical readiness of equipment, as well as the presence of technical interruptions in the mining-andtransport complex operation. It is taken on the model that the shift time, as on a real object, is 720 minutes. Then, according to the accepted methodology for simulation modelling of the mining-and-transport complex operation, in order to proceed to the modelling results for the period, the decrease in the performance of the mining-and-transport complex during day shifts is taken into account caused by interference with the auxiliary equipment operation, repair and maintenance work performed - 0.6-0.65 and also the days of blasting operations $-03-0.35$.

A significant difference between the two basic options design and simulation - is observed in the values of the distances for transporting overburden rock from the face to the dump, as well as coal to the unloading point (coal warehouse). For overburden rock, the deviation is $5.8 \%$, for coal $7.4 \%$. This is due to the difference in approaches to setting this parameter. In the first case, it is determined purely geometrically from one centre of mass to another, without taking into account the mining-and-transport complex operation. In the case of simulation modelling [24]-[27], this figure is summed up from the actual distance travelled by the dump trucks from the three points of loading overburden rock, taking into account the number of travels in each direction, which, in turn, also depends on the models of loading and transport equipment [28]-[30].

The deviations in the motion speed of dump trucks transporting overburden rock and coal of 4.4 and $31.8 \%$, respectively, are also natural. According to the project, for both models of dump trucks, this speed is taken equal to $25 \mathrm{~km} / \mathrm{h}$. This parameter is taken directly from the design methodology, based on the safety conditions of the vehicles movement. When constructing the model, the following parameters should be considered, which are significant in their influence on the dump trucks motion speed. These are the coefficient of performance (efficiency) and engine power, the payload weight of the dump truck (the weight of the loaded rock mass), movement in the cargo and empty directions, the number of vehicles in the travel (the factor of mutual interference and expectations is taken into account), the quality of the road surface [31]. When designing, the speed is traditionally taken as single-valued in directions, but in reality it differs by 30 $40 \%$. On the model, the difference in the speeds for overburden $(23.9 \mathrm{~km} / \mathrm{h})$ and coal $(17.04 \mathrm{~km} / \mathrm{h})$ is more than $6 \mathrm{~km} / \mathrm{h}$, which is explained by the different density of these rocks, as well as the specifics of the used transport models.

In accordance with the change in speed, the travel time of dump trucks has also changed, amounting to 0.95 and
37.8 percent, respectively. Depending on the motion speed of vehicles, there are similar deviations in the travel time. In addition to the movement time, the travel time is also affected by the difference in the procedure for downtime accounting of mining-and-transport equipment. If in the first case downtime is not taken into account in the calculations, then in the second case, they are formed based on the actual downtime, which, in turn, depends on a large number of factors. Among them are the motion speed and the number of vehicles, the organization of transportation and the interaction of dump trucks with loading and unloading equipment, the structure of the highway, etc.

In the design option, within the framework of simulation modelling, it is assumed that the dump trucks are new. Accordingly, their transmission and engine efficiency is taken at the level of 0.88 . In this case, the age of dump trucks is not taken into account, as it is assumed that over the years they do not change their state and their performance remains the same. In the modelled option 2 , the costs of mining-andtransport operations, with $100 \%$ fulfilment of annual volumes, amount to $1.13 \$ / \mathrm{m}^{3}$. Since the depreciation period of dump trucks is really existing, then when substantiating the designed mining-and-transport complex, it is expedient to take into account the age and state of the vehicles.

Option 3 provides for modelling the mining-and-transport complex operation in completely similar operating conditions, but, with account of the vehicle state, as well as the stages of introducing new equipment in the eighth year of the field development. As a result, the volume of overburden rock has decreased by $33.47 \%$, and coal production $-5.04 \%$, which ensures an increase in the costs of mining-andtransport operations to $1.90 \$ / \mathrm{m}^{3}$, or by $68.25 \%$.

The results of modelling the mining-and-transport complex operation during the double-flank mining of the field, presented in Table 1, have revealed that the project provides for a certain speed mode and different quality of road surface in the open-cut colliery on temporary and permanent sections of the highway. However, the presented calculations, made in the traditional way, do not take into account these factors, except for the average speed of dump trucks movement $25 \mathrm{~km} / \mathrm{h}$ with the same road surface - rolled earth surface, which, according to the accepted design standards, corresponds to the category III quarry roads. As the modelling results evidence, all other things being equal, namely miningengineering, mining-geometrical, mining-and-geological, economic and organizational conditions of the mining-andtransport complex proposed by the project, there are also significant deviations in some of the main technical and economic indicators. These include the average time of dump trucks movement in the travel and the average travel time, the number of travels and the number of vehicles required, and, consequently, the shift performance of dump trucks and the miningand-transport complex of the open-cut colliery as a whole.

One of the research options, in the case of using a doubleflank mining scheme, is associated with determining the influence of the speed limiting factor, which exists in practice and is partially prescribed in the explanatory note to the project. However, there is no mechanism for their adequate accounting in the calculations. In option 3, in maneuver areas of loading/unloading points, the ground rolled surface is replaced with a temporary one and speed limits of $5 \mathrm{~km} / \mathrm{h}$ are introduced, as it is in the case of practice within the framework of the safety system for mining-and-transport operations. 
Table 1. Comparing the calculation results of the traditional method and with dynamic modelling

\begin{tabular}{|c|c|c|c|c|c|}
\hline \multirow{2}{*}{ Indicator name } & \multicolumn{2}{|c|}{ Traditional } & \multicolumn{2}{|c|}{ Modelling } & \multirow{2}{*}{ Comments and notes } \\
\hline & Rock & Coal & Rock & Coal & \\
\hline Dump truck models & $\begin{array}{c}\text { Hitachi } \\
\text { EH3500ACII }\end{array}$ & $\begin{array}{l}\text { Hitachi } \\
\text { EH1700 }\end{array}$ & $\begin{array}{c}\text { Hitachi } \\
\text { EH3500ACII }\end{array}$ & $\begin{array}{l}\text { Hitachi } \\
\text { EH1700 }\end{array}$ & \multirow{2}{*}{$\begin{array}{l}\text { Adopted according to the project } \\
\text { before optimization }\end{array}$} \\
\hline Excavator models & $\begin{array}{c}\text { Hitachi } \\
\text { EX5600-6 }\end{array}$ & $\begin{array}{l}\text { Hitachi } \\
\text { EX1900 }\end{array}$ & $\begin{array}{c}\text { Hitachi } \\
\text { EX5600-6 }\end{array}$ & $\begin{array}{l}\text { Hitachi } \\
\text { EX1900 }\end{array}$ & \\
\hline$N_{e x}-$ number of excavators, pcs & 4 & 2 & 4 & 2 & Positioned in space \\
\hline Transportation direction & dump & $\begin{array}{l}\text { ware- } \\
\text { house }\end{array}$ & dump & $\begin{array}{l}\text { ware- } \\
\text { house }\end{array}$ & Control over loading and quality \\
\hline $\begin{array}{l}g_{n}-\text { nominal load capacity } \\
\text { of a dump truck, } \mathrm{t} \\
g_{a}-\text { adopted load capacity, } \mathrm{t}\end{array}$ & $185 / 168$ & $100 / 96$ & $185 / 168$ & $100 / 96$ & $\begin{array}{c}g_{n}=V_{b} \cdot q / K_{\text {loos }} \\
V_{b}-\text { body capacity; } \\
q-\text { bulk density of rock, } \mathrm{t} / \mathrm{m}^{3}\end{array}$ \\
\hline $\begin{array}{l}V_{a}-\text { volume of the platform } \\
\text { with a header, } \mathrm{m}^{3}\end{array}$ & 115 & 100 & 115 & 100 & Capacity control on the model \\
\hline$T_{s h}-$ one shift time, $\min$ & 660 & 660 & 720 & 720 & $\begin{array}{l}\text { With account of the conversion } \\
\text { factor } 0.85=612 \mathrm{~min}\end{array}$ \\
\hline$L_{t r . d}-$ transportation distance, $\mathrm{km}$ & 7.267 & 7.24 & 7.30 & 7.20 & Geometric/weighted average \\
\hline$V_{a v}-$ average travel speed, $\mathrm{km} / \mathrm{h}$ & 25 & 25 & 25.11 & 24.80 & Regulated by accepted norms \\
\hline $\begin{array}{l}T_{m o v}-\text { time of the dump truck } \\
\text { movement during the travel, min }\end{array}$ & 34.88 & 34.75 & 37.41 & 42.40 & $\begin{array}{l}\text { Based on the dump truck } \\
\text { traction performance }\end{array}$ \\
\hline$T_{\text {down }}-$ total time of downtime, $\min$ & - & - & 931.00 & 316.72 & Formed based on the conditions \\
\hline$q-$ bulk density of rock, $\mathrm{t} / \mathrm{m}^{3}$ & 2.2 & 1.25 & 2.2 & 1.25 & $\begin{array}{l}\text { In fact and according } \\
\text { to the project }\end{array}$ \\
\hline Kloos - loosening coefficient & 1.35 & 1.3 & 1.35 & 1.3 & $\begin{array}{c}\text { In fact and according } \\
\text { to the project }\end{array}$ \\
\hline$T_{t r}-$ travel time, $\min$ & 38.68 & 39.522 & 41.4 & 47.6 & $T_{t r}=T_{m o v}+T_{\text {l.m. }}+T_{\text {load }}+T_{\text {unl.m }}+T_{\text {unl }}$ \\
\hline$T_{l . m .}-$ load manoeuvre time, $\min$ & 0.5 & 0.5 & 0.64 & 0.56 & $\begin{array}{c}\text { Calculated with account } \\
\text { of manoeuvres }\end{array}$ \\
\hline$T_{\text {load }}$ - dump truck loading time, min & 2.13 & 4.826 & 1.60 & 4.67 & $\begin{array}{l}\text { Adopted according to the } \\
\text { project/calculation }\end{array}$ \\
\hline$T_{\text {unl.m }}$ - unload manoeuvre time, min & 0.5 & 0.5 & 0.64 & 0.56 & $\begin{array}{c}\text { Calculated with account } \\
\text { of manoeuvres }\end{array}$ \\
\hline $\begin{array}{l}T_{\text {unl }}-\text { dump truck unloading } \\
\text { time, min }\end{array}$ & 0.47 & 0.47 & 0.50 & 0.45 & $\begin{array}{l}\text { Adopted according to the } \\
\text { project/calculation }\end{array}$ \\
\hline $\begin{array}{l}Q_{s h}-\text { shift performance } \\
\text { of the dump truck, } \mathrm{m}^{3} / \mathrm{t}\end{array}$ & 1603.55 & 1478.91 & 1300.25 & 1344.00 & $\begin{array}{c}Q_{s h}=Q_{p e r f} N / \text { with account } \\
\text { of enlargement } \\
Q_{p e r f}-\text { one-hour performance; } \\
N / s h \text { - shift duration, h }\end{array}$ \\
\hline $\begin{array}{l}N_{t r}-\text { number of dump truck } \\
\text { travels per shift, travel }\end{array}$ & 15.77 & 15.43 & 17.03 & 14.00 & $N=\left(T_{\text {sh }}-\left(T_{\text {sh.ch }}+T_{\text {fuell }}+T_{p . n}\right) /\left(T_{t r}\right)\right.$ \\
\hline$T_{\text {sh.ch }}$ - shift change time, min & 30 & 30 & 50 & 50 & $\begin{array}{l}\text { Plus time at the end of the shift } \\
\text { to return to the park }\end{array}$ \\
\hline $\begin{array}{l}T_{\text {fuell }}-\text { time for fuelling } \\
\text { the dump truck, min }\end{array}$ & 10 & 10 & \multirow{2}{*}{\multicolumn{3}{|c|}{ Included in the shift change, at the beginning and end of the shift }} \\
\hline$T_{p . n}-$ time for personal needs, $\min$ & 10 & 10 & & & \\
\hline $\begin{array}{l}Q_{\text {year }}-\text { dump truck annual } \\
\text { performance, thousand } \mathrm{m}^{3}\end{array}$ & 967.74 & 800.00 & 785.57 & 833.95 & $\begin{array}{c}Q_{\text {yea }} r=Q_{s h} \cdot N_{\text {sh }} \cdot K_{\text {eng.rep }} \cdot K_{\text {tech.read }} / 1000 \\
N_{\text {sh }}-\text { number of shifts per year; } \\
K_{\text {eng.rep }}-\text { coefficient of accounting } \\
\text { the time of repair and replacement } \\
\text { of engines; } \\
K_{\text {tech.read }}-\text { technical readiness } \\
\text { coefficient }\end{array}$ \\
\hline $\begin{array}{l}\text { Planned performance/ } \\
\text { actual, thousand } \mathrm{m}^{3} / \mathrm{t}\end{array}$ & 30000 & 6400 & 29851.69 & 6671.62 & Accepted/by results of modelling \\
\hline$C_{s p}-$ specific current costs, $\$ / \mathrm{m}^{3}$ & \multicolumn{2}{|l|}{-} & \multicolumn{2}{|c|}{2.63} & The result of integrated calculations \\
\hline$N_{\text {d.tr }}-$ dump truck fleet, pcs & $30.57=31$ & $7.15=8$ & 37 & 8 & Accepted/by results of modelling \\
\hline
\end{tabular}

The option modelling has shown that if in option 2 the degree of fulfillment of the plan for rock mass is $99.92 \%$, then in the case of speed limits introduction only in the areas of dump truck maneuvers at loading/unloading points, this indicator decreases to $99.33 \%$ or $0.59 \%$. This leads to an increase in the specific current costs for rock mass by $0.287 \%$ or $0.007 \$ / \mathrm{m}^{3}$. With the project's annual performance of 35120 thousand $\mathrm{m}^{3}$, the negative economic effect only in terms of costs is 265.54 thousand \$/year.
On a separate basis, the influence of speed limits on the vehicles' movement along the quarry horizons is studied in option 4 . The project prescribes a speed limit when moving along the horizons of the open-cut colliery and over the dumps at the level of $15 \mathrm{~km} / \mathrm{h}$ both in the cargo and in the empty directions. On the access tracks, the movement of dump trucks in the cargo direction is not more than $16 \mathrm{~km} / \mathrm{h}$, and in the empty direction up to $30 \mathrm{~km} / \mathrm{h}$. 
When driving on the surface, the speed limit is $30 \mathrm{~km} / \mathrm{h}$. In this case, the performance of the mining-and-transport complex in terms of rock mass is already $88.96 \%$, or the decrease is another $10.37 \%$ from the previous option. The indicator of a unit costs of rock mass in this option is $2.92 \$ / \mathrm{m}^{3}$, which, compared to the previous option, increases by $0.18 \$$, which, given the annual volumes, leads to a negative economic effect of 6405.54 thousand \$/year.

In option 5, such a fundamental factor in opencast mining with vehicles as a speed limit of the dump trucks movement at intersections is assessed, which influences on the general technical and economic indicators. With traditional approaches to calculating the transport operations, this cannot be done adequately. The limit set is $10 \mathrm{~km} / \mathrm{h}$. In this option, the performance of the mining-and-transport complex decreases to $87.03 \%$, which in terms of volume amounts to $1224 \mathrm{~m}^{3} / \mathrm{cm}$ or 759.76 thousand $\mathrm{m}^{3} /$ year. The increase in the costs of miningand-transport operations in the specific indicator amounts to $0.046 \$ / \mathrm{m}^{3}$. The negative economic effect for a given volume of rock mass in this case is 1600.95 thousand \$/year.

Another important issue in the calculations when designing the mining-and-transport complexes is the qualitative accounting of the age and technical state of vehicles. Traditionally, in calculations, as in the project for the Kushmurun coal field development, dump trucks are taken as new with the appropriate transmission efficiency.

In option 6 , this indicator is taken equal to 0.85 , although for foreign-made dump trucks it can be 0.9-0.92. With a depreciation period of about 7-8 years at the accepted standards, the average indicator of transmission efficiency for dump trucks with a service life of 3-4 years, taking into account scheduled repairs and replacement of engines, is taken equal to 0.65 . For such a technical state of the dump truck fleet, under all other conditions, the performance of the mining-and-transport complex decreases to $79.77 \%$, which in the market volume amounts to $4282.02 \mathrm{~m}^{3} / \mathrm{cm}$ or 2656.99 thousand $\mathrm{m}^{3} /$ year. At the same time, the indicator of unit costs for mining-and-transport operations increases to $3.46 \$ / \mathrm{m}^{3}$, which is by $0.59 \$$ more than the same indicator in the previous option. The negative economic effect in this case is 20784.15 thousand \$/year.

With regard to option 6 , it should be noted that in real life, the age of dump trucks for each vehicle or for their groups is usually different. Vehicles with a transmission efficiency range from 0.4 to $0.85-0.9$ run in the fleet. This differs from the previous option, first of all, in that dump trucks with low transmission efficiency suppress the operation of dump trucks with a high value of this indicator, which leads, in conditions of a large number of vehicles, to even greater negative effects.

Option 7 studies just such a kind of state of the dump trucks nominal list. In this case, performance decreases to $68.64 \%$ or by $6266.41 \mathrm{~m}^{3} / \mathrm{cm}$, for coal it is $67.945 \%$, and for overburden rock - $68.76 \%$; the costs for coal production increase to $3.70 \$ / \mathrm{m}^{3}$; the negative economic effect is $8361.98 \$$ thousand/year.

Option 8 reveals the real amount of transport required to ensure the implementation of the planned volumes of coal production and recoverable overburden rock mass in the projected and close to reality mining-engineering, mininggeometrical, mining-and-geological, economic and organizational conditions. As evidenced by the results, ensuring the specified volumes of rock mass at the level of $100.05 \%$ will require 72 dump trucks in the working fleet and 79 vehicles in the nominal list. Among them 56 dump trucks of the Hitachi EH3500ACII model operate on the removal of overburden mass and 16 dump trucks of the Hitachi EH1700 model are involved in the transportation of coal. This is by 27 vehicles more than in the option corresponding to the calculated ones under the conditions that allow taking into account the standard approach. In this case, the costs of mining-andtransport operations increase to $3.77 \$$, which is by $1.14 \$$. exceeds the same indicator in the basic option. Thus, the total negative economic effect is 39199.93 thousand \$/year.

When comparing the two options of the Kushmurun coal field development, it can be seen that double-flank simultaneous mining of the deposit is a bit more economically effective, despite a significant increase in the length of roads and the costs for its maintenance [32]-[35]. Despite the increase in mileage and travel time, slightly higher travel speeds, lower specific fuel consumption cover these costs and disadvantages, and the mining-and-transport complex fulfils the planned volumes due to a smaller amount of vehicles. The resulting difference in costs of $0.032 \$ / \mathrm{m}^{3}$ provides a total annual effect of $1122.20 \$$ thousand/year.

According to the most economically viable option, the possibility of increasing the efficiency of mining-andtransport complex operation is studied by using dry soil and crushed stone surfacing treated with black binder on permanent road sections and with the subsequent introduction of a speed limit in both directions to $40 \mathrm{~km} / \mathrm{h}$ and reducing the depreciation period of dump trucks to 6 years (transmission efficiency is not lower than 0.6). As a result, an option has been obtained with $100 \%$ fulfilment of planned indicators using 10 Hitachi EH1700 dump trucks for coal and 45 Hitachi EH3500ACII dump trucks for overburden rock (61 vehicles in the nominal list) in the working fleet. At the same time, the unit cost is reduced to $3.26 \$ / \mathrm{m}^{3}$, which is lower by $0.51 \$$. In this case, the economic effect only due to the reduction in the costs of mining-and-transport operations will amount to 17896.63 thousand \$/year. It should be noted that the accelerated dump trucks depreciation, when the share of depreciation deductions for one dump truck increases, leads to a decrease in the depreciation fund for them, due to a decrease in their number, which is ensured by the increased efficiency of a less aged fleet of vehicles [36]-[39].

A general idea of the potential for improving the efficiency of design processes using methods and tools with advanced analytics is presented in Figure 3.

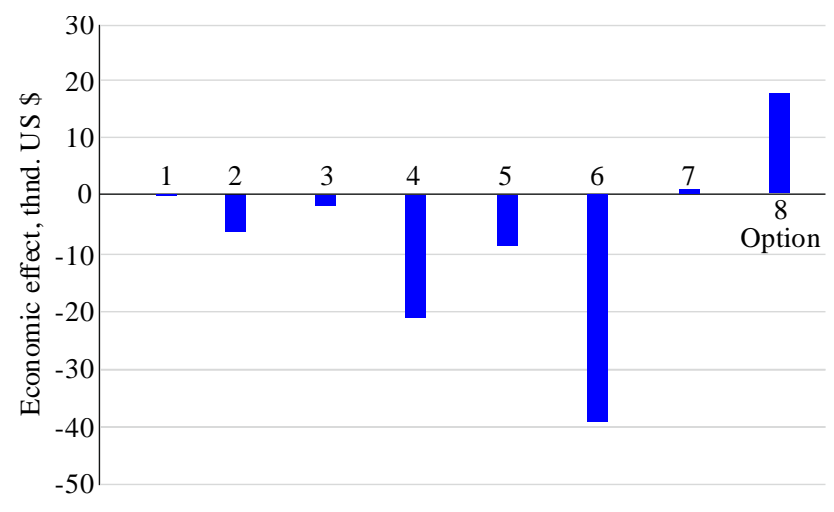

Figure 3. Comparative economic effect for eight options (thnd. US \$) based on the main costs when designing the miningand-transport geotechnological complex 
Based upon the results, for the most part, the traditionally applied design methodology, in terms of the main technical technological and economic indicators, leads to an underestimation of labour and energy costs. A significant part of the error is conditioned by the lack of proper adjustability to changes in parameters, which reduces the optimization measures effectiveness. The largest error is caused by the enlarged approach when determining the modes and operating conditions of mining-and-transport equipment, the inability to take into account its quality state during the entire service life.

Thus, an integrated technical and technological audit of a project for mining the Kushmurun field, performed on the basis of advanced analytics, has revealed that the proposed new methodological approach to the processes of designing and planning of mining-and-transport operations makes it possible to more adequately take into account in calculations a wide range of fundamentally important factors and provides for a significant overall economic effect during the field exploitation in the specified volumes. As the main conclusions on this stage of research performed within the framework of an integrated technical and technological audit of projects for mining the Abail and Kushmurun fields, the following can be noted.

\section{Conclusions}

Advanced digitalization and automation of design processes with appropriate methodological support of analytics can significantly increase the efficiency of designing the geotechnological complexes. On this information basis, it is possible to develop a unified methodology for calculations and assessing the effectiveness of technological processes, which can be used both at the designing and planning stages, and at the stage of geotechnological complexes exploitation.

When calculating vehicles, a significant potential is realized through high-quality accounting of such factors and parameters as: speed limits at intersections, at points of loading and unloading, road slope, number and influence of vehicles on each other, quality of road surface, age (service life) of vehicles, mutual influence of crisscross traffic flows, actual traction performance. The cumulative influence of these factors is more than $30 \%$, which is reflected in the number of required vehicles and associated with an increase in the total costs of mining-and-transport operations.

Due to the fact that the issue of updating the nominal list of vehicles at the stage of mineral deposits exploitation is practically inevitable, but, at the same time, there is also a factor of a significant decrease in the efficiency of the mining-andtransport complex when using jointly the vehicles with a significant difference in their technical state, one of the promising directions of increasing the efficiency of mining-and-transport operations in quarries using the road transport is the organization and regulation of the appropriate traffic flows.

When implementing an integrated technical and technological audit of projects for the mineral deposits development using simulation modelling, the necessity has been revealed to adjust the methodological and software support in order to create the possibility of adequate reproduction of the vehicles operation in various traffic flows based on the need to differentiate the vehicles with respect to different technical state.

With respect to a number of points (graphic display of the highway, corrected calculations for assessing the economic efficiency of the designed options, accounting of the traction performance of vehicles, etc.), the simulation modelling software has been improved in the process of research, which make it possible to eliminate the existing shortcomings and improve the quality of research.

In conditions of a long distance of rock mass haulage, the influence of the old transport used increases significantly and the economic damage grows in proportion to the increase in the haulage distance. Thus, the level of profitable age of the working fleet of vehicles increases. At the same time, the age range of the involved vehicle fleet is of great importance. The smaller it is, the more possible it is to reduce the average value of the profitable age of vehicles.

Research has shown that when designing mining-andtransport complexes, it is fundamentally important to determine both the economically feasible average age of vehicles and the threshold value of the oldest of them, beyond which their use leads to a significant decrease in the overall efficiency and profitability of the mining-and-transport complex operation. Accelerated depreciation of dump trucks, accompanied by an increase in depreciation deductions for one vehicle, leads to a decrease in the total depreciation fund and, ultimately, to a decrease in the costs of mining-and-transport operations, due to the greater efficiency of a less aged fleet of vehicles.

\section{Acknowledgements}

The paper has been prepared according to the programtargeted financing projects of Ministry of Education and Science of the Republic of Kazakhstan BR05236712; 2018/BR05235618.

\section{References}

[1] Sishi, M., \& Telukdarie, A. (2020). Implementation of Industry 4.0 technologies in the mining industry - a case study. International Journal of Mining and Mineral Engineering, 11(1), 1-22. https://doi.org/10.1504/ijmme.2020.105852

[2] Rylnikova, M., Radchenko, D., \& Klebanov, D. (2017). Intelligent mining engineering systems in the structure of Industry 4.0. E3S Web of Conferences, (21), 01032. https://doi.org/10.1051/e3sconf/20172101032

[3] Rysbekov, K., Toktarov, A., Kalybekov, T., Moldabayev, S., Yessezhulov, T., \& Bakhmagambetova, G. (2020). Mine planning subject to prepared ore reserves rationing. E3S Web of Conference, (168), 00016. https://doi.org/10.1051/e3sconf/202016800016

[4] Baibatsha, A., Omarova, G., \& Shakirova, G. (2019). Innovative technologies of mineral resources predictioin on covered territories. International Multidisciplinary Scientific GeoConference Surveying Geology and Mining Ecology Management, 19(1), 271-278. https://doi.org/10.5593/sgem2019/1.1/s01.033

[5] Stupnik, M., Kolosov, V., Kalinichenko, V., \& Pismennyi, S. (2014). Physical modeling of waste inclusions stability during mining of complex structured deposits. Progressive Technologies of Coal, Coalbed Methane, and Ores Mining, 25-30. https://doi.org/10.1201/b17547

[6] Dryzhenko, A., Moldabayev, S., Shustov, A., Adamchuk, A., \& Sarybayev, N. (2017). Open pit mining technology of steeply dipping mineral occurences by steeply inclined sublayers. International Multidisciplinary Scientific GeoConference Surveying Geology and Mining Ecology Management, 17(13), 599-606. https://doi.org/10.5593/sgem2017/13/s03.076

[7] Dychkovskyi, R., Vladyko, O., Maltsev, D., \& Cabana, E.C. (2018). Some aspects of the compatibility of mineral mining technologies. Rudarsko-Geološko-Naftni Zbornik, 33(4), 73-82. https://doi.org/10.17794/rgn.2018.4.7

[8] Galiyev, D.A., Uteshov, E.T., \& Tekenova, A.T. (2020). Digitalization of technological and organizational processes of mining operations due to the implementation of the installation system and accounting the key indicators. News of the National Academy of Sciences of the Republic of Kazakhstan, Series of Geology and Technical Sciences, 5(443), 47-53.

[9] Maldynova, A., Osmanov, Z., \& Galiyev, D. (2018). Formation of marketing strategy for promoting an innovative product. Journal of Applied Economic Sciences, 13(7), 1951-1958. 
[10] Baibatsha, A., Omarova, G., Dyussembayeva, K., \& Kassenova, A. (2016). Kokkiya - A promising for Kazakhstan gold-metasomatic type of deposit. International Multidisciplinary Scientific GeoConference Surveying Geology and Mining Ecology Management, (1) 289-296. https://doi.org/10.5593/sgem2016/b11/s01.037

[11] Lyashenko, V.I., Dyatchin, V.Z., \& Lisovoy, I.A. (2018). Increase of environmental safety of mining production on the basis of waste utilization of extraction and processing of ore raw materials. Ecology and Industry of Russia, 22(4), 4-10. https://doi.org/10.18412/1816-0395-2018$\underline{4-4-10}$

[12] Analysis of the effectiveness of modern design methods and development of a methodology for dynamic design of mining operations in open pits. (2018). Report on research work "Development of methodology for the design of mining operations, taking into account the operational digitalization of processes". Stage 1. Astana, Kazakhstan.

[13] Galiev, S.Zh., Alpysbaeva, Zh.T., \& Seytaev, E.N. (2018). Methods of dynamic design of mining and transport operations using methods of simulation and operational presentation of mining transport processes. Astana, Kazakhstan: LLP "Research Design Institute" KazTechProekt", $29 \mathrm{p}$.

[14] Galiev S.Zh., Sarsenbaev E.E., Alpysbaeva Zh.T., \& Seytaev E.N. (2019). Development of digitalization of the projected processes and the development of instructions for the design of mining and transport operations using modern information technologies. Report on research work on the topic "Development of methodology for the design of mining operations, taking into account the operational digitalization of processes". Stage 2. Astana, Kazakhstan, $50 \mathrm{~s}$.

[15] Galiev, S.Zh., Alpysbaeva, Zh.T., \& Seytaev, E.N. (2018). The effectiveness of automation in mining design based on in-depth digitalization. Materials of the International Scientific and Technical Conference dedicated to the $60^{\text {th }}$ Anniversary of the NMMC "Prospects for the Innovative Development of the Mining and Metallurgical Complex" (pp. 333-335). Navoi, Kazakhstan.

[16] Galiev, S.Zh., Galiev, D.A., Seytaev, E.N., \& Uteshov, E.N. (2019). Feasibility of a unified methodology for managing a geotechnological complex at opencast mines. Scientific-Technical and Industrial Mining Journal of Kazakhstan, (3), 36-41.

[17] Kuandykov, T., Nauryzbayeva, D., Yelemessov, K, Karmanov, T., Kakimov, U., \& Kolga, A. (2020). Development and justification of a hydro-impulse method for increasing ore permeability in conditions of uranium borehole production. News of the National Academy of Sciences of the Republic of Kazakhstan, Series of Geology and Technical Sciences, 6(444), 126-133.

[18] Galiev, S.Zh., Dovzhenok, A.S., Galiev, D.A., \& Uteshov E.T. (2020). Digitalization and the potential for increasing the efficiency of mining and transport operations at opencast mines. Izvestiya NAS RK, 1(439), 146-154. https://doi.org/10.32014/2020.2518-170X.18

[19] Anpilogov, A.E. (1971). Technological features of a coal mine with railway transport and their consideration when modeling on a computer. Improvement of Technology at Coal Mines, (2), 3-9.

[20] Krupnik, L., Yelemessov, K., Beisenov, B., \& Baskanbayeva, D. (2020). Substantiation and process design to manufacture polymer-concrete transfer cases for mining machines. Mining of Mineral Deposits, 14(2), 103109. https://doi.org/10.33271/mining14.02.103

[21] Kalybekov, T., Yunussov, R., Rysbekov, K.B., \& Soltabayeva, S.T. (2018). Control of reserves readiness and quality characteristics of ore in open pit mining. Proceedings of the $25^{\text {th }}$ World Mining Congress. Open-Pit Mining, 220-226.

[22] Rysbekov, K., Toktarov, A., Kalybekov, T., Moldabayev, S., Yessezhulov, T., \& Bakhmagambetova, G. (2020). Mine planning subject to prepared ore reserves rationing. E3S Web of Conferences, (168), 00016. https://doi.org/10.1051/e3sconf/202016800016

[23] Lozynskyi, V., Medianyk, V., Saik, P., Rysbekov, K., \& Demydov, M. (2020). Multivariance solutions about designing new levels of coal mines. Rudarsko Geolosko Naftni Zbornik, 35(2), 23-32. https://doi.org/10.17794/rgn.2020.2.3
[24] Moldabayev, S., Rysbaiuly, B., Sultanbekova, Z., \& Sarybayev, N. (2019). Methodological approach to creation of the 3D model of an oval-shaped open pit mine. E3S Web of Conferences, (123), 01049. https://doi.org/10.1051/e3sconf/201912301049

[25] Moldabayev, S. (2017). Management reserves of mining operations mode in open pit mining of steeply dipping mineral occurences. $17^{\text {th }}$ International Multidisciplinary Scientific GeoConference SGEM2017, Science and Technologies in Geology, Exploration and Mining, 519528. https://doi.org/10.5593/sgem2017/13/s03.066

[26] Moldabayev, S., Rysbayuly, B., Sultanbekova, Z., Aben, Y., \& Sarybayev, N. (2016). Dynamic model of new order of working zone forming realization on steep boards of oval form quarries. $6^{\text {th }}$ International Conference on Computer Applications in the Minerals Industries, 20(7).

[27] Chetverik, M., Bubnova, E., \& Babiy, E. (2013). The main technical solutions in rational excavation of minerals in open-pit mining. Annual Scientific-Technical Collection - Mining of Mineral Deposits, 173-176. https://doi.org/10.1201/b16354-30

[28] De la Torre, C.A., Bradley, B.A., \& Lee, R.L. (2020). Modeling nonlinear site effects in physics-based ground motion simulations of the 2010-2011 Canterbury earthquake sequence. Earthquake Spectra, 36(2), 856-879. https://doi.org/10.1177/8755293019891729

[29] Temkin, I.O., Klebanov, D.A., Deryabin, S.A., \& Konov, I.S. (2020). Construction of intelligent geoinformation system for a mine using forecasting analytics techniques. Mining Informational and Analytical Bulletin, (3), 114-125. https://doi.org/10.25018/0236-1493-2020-3-0-114-125

[30] Silkina, G.Yu. (2017). Information and communication technologies in ensuring of innovative development. $2^{\text {th }}$ International Business Information Management Association Conference - Education Excellence and Innovation Management through Vision 2020: From Regional Development Sustainability to Global Economic Growth, 129797.

[31] Rakishev, B.R., \& Galiev, D.A. (2015). Optimization of the ore flow quality characteristics in the quarry in road-rail transport. Metallurgical and Mining Industry, 7(4), 356-362.

[32] Ekaterina, K.-T. (2019). The parameters of the concession agreement for the construction of transport infrastructure within the framework of the complex mining project. International Multidisciplinary Scientific GeoConference Surveying Geology and Mining Ecology Management, 19(5), 869-875. https://doi.org/10.5593/sgem2019/5.3/S21.110

[33] Yakovlev, V.L., Zyryanov, I.V., Zhuravlev, A.G., \& Cherepanov, V.A. (2018). Features of modern approach to selection of haulage systems for open pit diamond mines in Yakutia. Journal of Mining Science, 54(6), 979-987. https://doi.org/10.1134/S1062739118065131

[34] Kruczek, P., Polak, M., Wyłomańska, A., Kawalec, W., \& Zimroz, R. (2018). Application of compound Poisson process for modelling of ore flow in a belt conveyor system with cyclic loading. International Journal of Mining, Reclamation and Environment, 32(6), 376-391. https://doi.org/10.1080/17480930.2017.1388335

[35] Valuev, A.M. (2018). Technologies of generating and selecting logistics scenario in operational open pit mine management. Mining Informational and Analytical Bulletin, (3), 32-39. https://doi.org/10.25018/0236-14932018-3-0-32-39

[36] Sladkowski, A., Utegenova, A., Elemesov, K., \& Stolpovskikh, I. (2017). Determining of the rational capacity of a bunker for cyclic-and-continuous technology in quarries. Naukovyi Visnyk Natsionalnoho Hirnychoho Universytu, (6), 29-33.

[37] Fedorko, G., \& Vasil', M. (2017). The use of simtalk program for modelling disconnection of rail vehicles in the mineral raw materials mining. International Multidisciplinary Scientific GeoConference Surveying Geology and Mining Ecology Management, 17(21), 703-710. https://doi.org/10.5593/sgem2017/21/S07.090

[38] Abroskin, A.S. (2015). Use of modern systems of automation of open cast mining. Bulletin of the Tomsk Polytechnic University, Geo Assets Engineering, 326(12), 122-130.

[39] Zhyravel, V., \& Zhyravel, I. (2015). Improvement of the industrial station design for better performance. Eastern-European Journal of Enterprise Technologies, 2(3), 61-67. https://doi.org/10.15587/1729$\underline{4061.2015 .40402}$

\section{Потенціал підвищення ефективності процесів проектування освосння родовищ твердих корисних копалин на основі цифровізації та поглибленої аналітики}

\section{Д. Галієв, С. Галієв, Д. Науризбаєва, К. Рисбеков, Е. Утєшов}

Мета роботи полягає у розвитку й адаптації наявної науково-методичної та програмно-інформаційної бази управління геотехнологічними комплексами для реалізації процесного підходу на рівні проектування і експлуатації гірничотранспортних комплексів на відкритих розробках. Розвиток пов'язаний з охопленням все більш актуальних варіантів екскаваторно-конвеєрних та екскаваторно-автомобільно-конвеєрних гірничотранспортних систем кар'єрів. 
Методика управління геотехнологічними комплексами полягає в адекватному післяопераційному обліку та відповідному оперативному регулюванні всіх основних факторів у конкретних гірничотехнічних, гірничо-геометричних, гірничо-геологічних, економічних і організаційних умовах. В якості основного методу застосовувався метод імітаційного логіко-статистичного моделювання гірничотранспортних процесів.

Результати показали, що спрощені аналітичні підходи і не адекватно враховувані фактори, що чинять істотний вплив на ефективність видобувних робіт, призводять до істотних погрішностей (10-20\% і більше), що визначає реальну практичну рентабельність освоєння родовищ корисних копалин.

Наукова новизна полягає в комплексному підході до єдиного об'єкту дослідження, яким є геотехнологічний комплекс, унікальне імітаційне логіко-статистичне моделювання гірничотранспортних процесів, економіка процесного управління, а також комплексне і корпоративне процесне управління.

Практична значимість. Отримані результати комплексного техніко-технологічного аудиту проекту освоєння вугільного родовища, з достатньою для практичного застосування точністю, забезпечать розвиток методологічної бази проектування, планування та управління гірничими і гірничотранспортними роботами, а також підвищення ефективності проведення наукових і науковопрактичних досліджень в даному напрямку, при вирішенні практичних завдань гірничого виробництва.

Ключові слова: корисна копалина, імітаційне моделювання, геотехнологічний комплекс, процес, управління

\section{Потенциал повышения эффективности процессов проектирования освоения месторождений твердых полезных ископаемых на основе цифровизации и углубленной аналитики}

\section{Д. Галиев, С. Галиев, Д. Наурызбаева, К. Рысбеков, Е. Утешов}

Цель работы заключается в развитии и адаптации имеющейся научно-методической и программно-информационной базы управления геотехнологическими комплексами для реализации процессного подхода на уровне проектирования и эксплуатации горнотранспортных комплексов на открытых разработках. Развитие связано с охватом все более актуальных вариантов экскаваторно-конвейерных и экскаваторно-автомобильно-конвейерных горнотранспортных систем карьеров.

Методика управления геотехнологическими комплексами заключается в адекватном пооперационном учете и соответствующем оперативном регулировании всех основных факторов в конкретных горнотехнических, горно-геометрических, горногеологических, экономических и организационных условиях. В качестве основного метода применялся метод имитационного логико-статистического моделирования горнотранспортных процессов.

Результаты показали, что упрощенные аналитические подходы и не адекватно учитываемые факторы, оказывающие существенное влияние на эффективность добычных работ, приводят к существенным погрешностям (10-20\% и более), определяющим реальную практическую рентабельность освоения месторождений полезных ископаемых.

Научная новизна заключается в комплексном подходе к единому объекту исследования, каковым является геотехнологический комплекс, уникальное имитационное логико-статистическое моделирование горнотранспортных процессов, экономика процессного управления, а также комплексное и корпоративное процессное управление.

Практическая значимость. Полученные результаты комплексного технико-технологического аудита проекта освоения угольного месторождения, с достаточной для практического применения точностью, обеспечат развитие методологической базы проектирования, планирования и управления горными и горнотранспортными работами, а также повышение эффективности проведения научных и научно-практических исследований в данном направлении, при решении практических задач горного производства.

Ключевые слова: полезное ископаемое, имитаиионное моделирование, геотехнологический комплекс, процесс, управление 